Competition law and the obligation to supply

Bergqvist, Christian

Publication date:

2015

Document version

Early version, also known as pre-print

Citation for published version (APA):

Bergqvist, C. (2015). Competition law and the obligation to supply. 


\section{Competition law and the obligation to supply}

In search of an obligation with more misunderstandings than actual scope and a slow incorporation into Danish law

By Christian Bergqvist ${ }^{1}$

While accepted in theory and practice that an obligation to supply, service or license can emerge under competition law, the scope of this is subject to many, if not lacunas, at least ambiguities, and no general obligations of such nature can, no should, be identified. Further, and equally important, the narrow set of circumstances warranting intervention against refusals is defined by competition law in accordance with its underlying principles of a predominantly economic nature. Hence, competition law should not be relied upon as a corrective instrument to lacunas in other areas of law, e.g. compulsory licenses under IP law. Below, some considerations regarding the obligation to supply under competition law are offered for the purpose of correcting the misunderstandings.

It is often suggested, but rarely developed further, that competition law could (and should) serve as a corrective instrument for regulatory lacunas, thereby resting e.g. the obligation to supply or conclude contracts on a competition law bed where the matter has not been resolved in a satisfactory manner under sector specific regulation. However, that presumption is for a number of reasons manifestly wrong, and a prudent approach to the matter would be to clear the misunderstandings from the outset. First and foremost, competition law should be viewed as an independent area of law and not a supplement to others areas. From a sector specific perspective, it might be attractive and convenient to view competition law, with its ex post application to a conflict, as a supplement to the ex ante review already conducted under sector specific regulation allowing for intervention against conflicts that have not been remedied in a satisfactory manner under the latter. However, that would de facto reduce competition law to an appendix to sector regulation rather than a stand-alone regulation and therefore represents a manifestly wrong perception of competition law. While competition law, in

${ }^{1}$ Christian Bergqvist, Ph.D. Associated Professor, Faculty of Law/University of Copenhagen. Comments are welcomed on cbe@jur.ku.dk 
certain limited situations, very well could supplement sector regulation by remedying defaults, it would be done in accordance with competition law doctrine and principles with little respect to any considerations enshrined in sector regulation. In short, competition law would serve on its own terms and with little, if any, regards to sector regulation, and interests advanced under this potentially giving a result unattractive from a sector perspective.

Secondly and partly linked to the first objection, competition law has matured to an area of law subject to its own requirement, doctrine and consideration requiring a (prudent) balancing of opposing interests that potentially could differ significantly from those enshrined in sector specific regulation. In the course of the last sixteen years, where competition law in Denmark has matured into a fully-fledged legal frame, it has emerged as a system linked to the pursuit of economic (long-term) efficiency and the protecting of the competition process rather than competition, and competitor, in itself. Hence, competition law does not take much interest in the specific consumer or competitor victimized by an infringement, but rather the general and broad interest of all consumers and competitors. Under competition law, it is therefore perfectly legitimate to eliminate competitors, provided that it follows from inefficiencies such as higher costs or lower quality and thereby limits the associated consumer loss significantly. Perhaps it might even be allowed to eliminate an equally efficient competitor if this suffers shortage of credit or cash or for other business based reasons, provided that it does not lead to the elimination of all competitors or the last of these, tilting the market conditions in favour of a monopoly, presumably contradictive to the interest of consumers and the market. Further, ex post competition law enforcement is rarely called into actual service but rather works behind the scenes through credible, and deterrent, remedies that few companies desire to encounter. Notably would also be that the actual enforcement is done by a general body with very limited sector specific knowledge, or consideration, in accordance with a lengthy and prudent process enshrining checks and balances to which plaintiff would not be considered party. ${ }^{2}$ Sector specific regulation could in contrast differ on numerous accounts, e.g. by pursuing other objectives such as fairness or swiftness and by its enforcement by a designated sector regulator incorporating sector knowledge and by hammering out obligations in details, emphasizing the mitigation of conflict ex ante rather than the resolving ex post. Further, acting as a mediator, rather than an enforcer, the Agency would normally attempt to strike a fair balance of

\footnotetext{
${ }^{2}$ See Copenhagen Malmö Port AB mod Konkurrencestyrelsen, the Competition Appeals Board's decision of 13 September 2007.
} 
opposing interests with a high degree of involvement from the plaintiff and the defendant.

Thirdly, it has been articulated directly in e.g. the Danish Competition Act, ${ }^{3}$ and de facto accepted under EU competition law, ${ }^{4}$ that competition law yields where a matter has been regulated by sector specific regulation and conflicts are presumably internalized. Hence, competition law could in principle not serve as a corrective instrument for regulatory lacunas, even where the matter obviously eludes sector regulation or produces an unsatisfactory or anti-competitive result. ${ }^{5}$ While the scope of the obligation and the embedded doctrine are subject to a number of ambiguities, e.g. where no decision has been rendered by a sector regulator, it is obvious that this doctrine limits the ability of competition law to close regulatory gaps or shortages in sector regulation. Consequently, competition law should not be relied upon as a corrective instrument to general lacunas in other areas of law, e.g. compulsory licenses under IP law, without entirely precluding the possibility. In a (narrow) set of circumstances, intervention against a refusal to supply might be available under competition law. This will be developed further below, followed by a few considerations as to the use of competition law to correct lacunas. The later will be offered despite the initial dismissal of the ability to do this.

\section{Competition law and refusal to supply}

Despite the reservation outlined above, a (narrow) obligation to supply could be established under competition law in accordance with one of the following doctrines:

1. Refusal to supply could potentially foreclosure the market, subject to the requirements that a) the suppler is dominant ${ }^{6}$ and b) the product or service in question is essential for the long term survival of the parties

${ }^{3}$ Pursuant to Article 2 (2) of the Danish Competition Act, the act and its obligations are not applicable to restrictions that follow directly from public regulation.

${ }^{4}$ See Nicolas Petit, Circumscribing the Scope of EC Competition Law in Network Industries? A Comparative Approach to the US Supreme Court Ruling in the Trinko Case, Journal of Network Industries, 5: 2004 pp. 347-362.

${ }^{5}$ An example of this can be seen in Terminal A - Konkurrencerådets beslutning om at rette henvendelse til transportministeren af 25. januar 2012, the Competition Council meeting 12. January 2012 where it somewhat late in the process was uncovered that public regulation precluded further pursuing of the case under Competition Law.

${ }^{6}$ The issue of dominance will not be discussed further in this article. However, normally market shares in excess of $40 \%$ would be required before dominance could be established. For further discussions on the issue, see Luis Ortiz Blanco, Market Power in EU antitrust law, Hart Publishing 2012. 
requesting supplies. A variation of this doctrine is the disruption of ongoing and current supplies. While in principle subject to the same requirements, the essentiality discussion might be of less importance as an abrupt termination could shake most companies. Hence, a legal distinction between the de nova refusal and disruption of supplies might be relevant. Further, the latter would presumable also cover different forms of sabotage and constructive refusal to supply.

2. Discriminatory refusal of supply, where only a limited number of companies are offered terms without a valid course. While in principle subject to the same requirements as doctrine 1 , the discriminatory element could in practice taint the appraisal and ease the essentiality discussion.

3. A collective refusal to supply, where companies agrees to boycott a named third party with the intention of foreclosing him. While foreclosure should in principle require that the parties have market power and that the product in question could be considered essential, practice indicates that these criteria tend to be treated somewhat superficially.

As indicated by the doctrines outlined above, competition law does not provide for a refusal-to-supply-doctrine but rather a prohibition of the monopolization of the market - either unilaterally under section 11 of the Danish Competition Act, mirroring Article 102 of the TFEU, or collectively under section 6 of the same act, mirroring Article 101 of the TFEU.

\section{The fall of a doctrine and rise of a set of exceptional circumstances}

Prior to Denmark's adoption of a modern EU conform competition law in 1997, a somewhat light handed refusal-to-supply-doctrine had emerged, more or less compelling dominant undertakings to supply absent (strong) objective reasons. A doctrine applied vigorously against companies resulting in an overdeveloped catalogue of objective reasons meriting exceptions and few possibilities to elude the obligation outsides these. In contrast, the EU Commission had, guided by the European Court of Justice, moved down an alternate path. While in principle accepted, c.f. Commercial Solvents ${ }^{7}$ (1974), $U B C^{8}$ (1978), $I B M^{9}$ (1984) and Telemarketing ${ }^{10}$ (1985), that Article 102 limited the dominant undertaking's freedom to contract if motivated by

\footnotetext{
${ }^{7}$ Case C-6 and 7/73 - Commercial Solvents Corporation. ECR 1974 p. 223.

${ }^{8}$ Case C-27/76 - United Brands Company, ECR 1978, p. 207.

${ }^{9}$ XIV Report on Competition (1984), recitals 94-95. See also case IV/30.979 and 31.394 - Decca Navigator System, O.J. 1989 L43/27.

${ }^{10}$ Case C-311/84 - Telemarketing (CBEM), ECR 1985, p. 3261.
} 
dubious motives, e.g. an ambition to reserve a secondary market or discourage occasional trading with competitors on the main market, the prevailing doctrine would gradually shift away in favour of the essential nature of the disputed products or services. Further, UBS even opened a (narrow) window for the dominant undertaking's right to protect its own commercial interest, e.g. on the main market, when deciding to discontinue, or open, a trading relationship. ${ }^{11}$ Consequently, what emerged was a doctrine that, despite condemning refusals motivated by anticompetitive objectives, would emphasize the objective consequences of the refusal rather than its subjective motive. Further, the doctrine introduced an important, but not entirely clear, distinction between vertical and horizontal foreclosures where the first, which deals with access to a downstream market, was less likely to be permissible compared to the latter, ${ }^{12}$ which deals with access to the dominated market.

While the notion of essentiality initially appeared to have played a less pivot role, ${ }^{13}$ this would change. The first set of changes came about through a serie of three harbour cases, B\&I v. Sealink,${ }^{14}$ R $\phi d b y ~ H a v n{ }^{15}$ and Sea Containers v. Stena Sealink, ${ }^{16}$ delivered between 1992 and 1994 and involving a cocktail of discretionary terms and plain malicious (ab)use of harbour authority. ${ }^{17}$ In all of these cases, the Commission referred to the involved harbour services as essential facilities that could not be reserved exclusively for the benefit of the dominant undertaking or shared under terms less favourable than those granted to the own services of the dominant undertaking. Despite the clear anti-competitive motive and an indefensible behaviour, it was allegedly the essential nature of the involved services that merited intervention from the Commission rather than the malicious abuse. This was enshrined further with four subsequent cases involving rail operations. $\mathrm{HOV}$

${ }^{11}$ Case 27/76 - UBC, ECR. 1978, p. 207, recital 189. See also case 77/77 - BP, ECR. 1978 p. 1513, recitals 18 and 32; case IV/32.279 - BBI/Boosey \& Hawkes O.J. 1987L 286/36 and Filtrona/Tabacalaera - XIX Report on Competition Policy (1989), recital 61.

12 For further, see Robert O'Donoghue and Jorge Padilla, The Law and Economics of Article 102, Second Edition, Hart Publishing 2013, pp. 541-542.

${ }^{13}$ See e.g. cases C-6 and 7/73 - Commercial Solvents Corporation. ECR 1974 p. 223, recital 15 and 26 where the relevance of existing alternative suppliers largely was ignored.

${ }_{14}^{14}$ Case B\&I v. Sealink , 1992, XXII Report on Competition (1992), recital 219.

${ }^{15}$ Commission Decision of 21 December 1993 concerning a refusal to grant access to the facilities of the port of Rødby, O.J. 1994L 55/52, recital 12.

${ }^{16}$ Case IV/34.689 - Sea Containers v. Stena Sealink, O.J. 1994L 15/8, recital 66.

${ }^{17} B \& I v$. Sealink offers a primar facia example of this as Sealink, which also served in the capacity of port authority, had timed its own ferry sailing times in a way that would cause maximum damage to B\&I operations. Due to the port's limitations when a Sealink vessel passes a moored B\&I ship, the water in the harbour would rise, making it required to disconnect loading and unloading operations. 
SVZ/MCN,${ }^{18}$ ACI,${ }^{19}$ European Night Services ${ }^{20}$ and Eurotunnel, ${ }^{21}$ all decided by the Commission in a narrow span between March and December $1994,{ }^{22}$ and implying an obligation to offer non-discriminatory access to essential infrastructure facilities.

Jointly these cases would give ground for a European version of the Essential Facility Doctrine, compelling dominant undertakings to offer shared use of certain non-replicable (infrastructure) facilities and hence conclude, and maintain, supply agreements absent (legitimate) cause. Consequently, it was not without merits when the Commission in its Access Notice ${ }^{23}$ from August 1998 could summarize that an obligation to offer access to an unreplicable facility could emerge if:

a) access to the requested facility was essential in order for companies to compete on a related market,

b) there was sufficient capacity available to provide access and no objective justification for refusing it,

c) the company tabling the request was willing to pay a reasonable and non-discriminatory price and to accept other fair terms and conditions,

d) the facility owner fails in meeting demand on an existing service or product market, blocks the emergence of new services or products or otherwise impedes competition on an existing or potential market.

Further, as demonstrated by early cases as IBM and Telemarketing, it did not matter whether the requested product was a service, facility or product. All could become subject to an obligation to offer terms. Neither did the absence of special rights, public funding or authority matter, rendering Article

${ }^{18}$ Case 33.941 - HOV SVZ/MCN, O.J. 1994L 104, p. 34. Upheld by T-229/94 - Deutsche Bahn.

${ }^{19}$ Case IV/34.518 - ACI, O.J. 1994L 224 p. 28.

${ }^{20}$ Case IV/34.600 - Night Services O.J. 1994L 259, p. 20. The case did not relate to Article 102 but the appraising of a joint venture under Article 101 (3) and was further overturned by the General Court. The prevailing principle does, however, offer guidance on Article 102.

${ }^{21}$ Case 32.490 - Eurotunnel, O.J. 1994L 354 p. 66.

${ }^{22}$ European Night Services and Eurotunnel where both overturned by the General Court. However, their original form illustrates the Commission's initial perception of a refusal to supply doctrine in the mid 1990s.

${ }^{23}$ Notice on the application of the competition rules to access agreements in the telecommunications sector - framework, relevant markets and principles. O.J. 1998C 265, pp. 2-28, recital 91. However, it should be noted that the notice does not cite UBS in respect to the right to protect self-interest as indicated. It is not clear why. Either the Commission does not accept the right or it has limited itself to outline the general principles. 
106 admissible, ${ }^{24}$ as demonstrated by Commercial Solvents, UBC and IBM. All cases where refusals initiated by privately operated and funded companies merited condemnation. Not even IP right was sacred as demonstrated by Magil, ${ }^{25}$ finally closed in 1995 , and involving the somewhat dubious retaining of the weekly schedules of television channels requested for the purpose of consolidating them into a single TV guide covering all channels. A product for which there was a clear consumer demand in the absence of a comparable service. However, while upholding the Commission's assessments, even expanding the doctrine to cover IP rights, there was nevertheless a double-edged element to Magil as it also would sow the seeds of a gradual reframing of the doctrines. Rather than utilizing the wording of previous cases, e.g. by labelling IP rights as essential if license was a precondition for effective market entry, the Court of Justice reserved intervention for exceptional circumstances, thereby giving rise to a slightly alternative doctrine. Further, the court noted that absent license, the development of a new product for which there was a clear consumer demand had been suppressed. An initially unnoticed remark that later would come back and haunt the Commission with vengeance.

\section{Reframing the doctrine and tightening the requirements}

While Magil had identified an obligation to license subject to the requirement of exceptional circumstances, the scope of this concept remained somewhat foggy until Night Service ${ }^{26}$ and Bronner ${ }^{27}$ delivered September and November 1998. While the first provided an overturn of the Commission's negative appraisal of a joint venture established to offer services through the Channel Tunnel in the absence of two vertically linked markets and a potential foreclosure of one of these, the later specifically dealt with what to consider exceptional circumstances. A request tabled by an Austrian court dealing with a national refusal to supply case and therefore in need for

${ }^{24}$ Article 106 (1) of the TFEU deals with undertakings granted special or exclusive rights by public act or other public instrument, and is in conjunction with Article 102 generally perceived to tighten the appraisal of potential anti-competitive behaviour compared to a pure Article 102 case. For further on Article 106 (1) and abusive behavior, see e.g. Richard Whish and David Bailey, Competition law, $7^{\text {th }}$ edition, Oxford 2012, pp. 229-235.

${ }^{25}$ Case C-241/91P and 242/91P - Radio Telefis Eireann (RTE) and Independent Television Publications Ltd (ITP) v. the Commission, ECR. 1995, p. I. 743. See in particular recitals 49-56. Reviewing the case, it appears that the Commission had some reservation in accepting the requested information as IP rights, and it cannot be excluded that this has materially influenced the case.

${ }^{26}$ United cases T-374/94, T-375/94, T-384/94 and T-388/94 - European Night Services Ltd (ENS) and others, ECR. 1998 p. II-3141. See in particular recitals 185-187 and 208-209.

${ }^{27}$ Case C-7/97 - Oscar Bronner, ECR. 1998 p. I-7791. See in particular recitals 40-46. 
guidance. Both cases are notable and have contributed significantly to our understanding of the concept of abuse. Assuming that the Commission pursued Night Service against the notion of the Channel Tunnel as an essential facility under the essential facility doctrine, it is difficult not to see the General Court decision as a blow against both. Further, in Bronner, the Court of Justice replied that an abuse would require two vertically linked markets where the requested product could be considered indispensable for the ability to access the second in the absence of realistic alternative, making a foreclosure from this plausible. The national court should therefore check for alternatives, even if these might be less attractive or unavailable for lack of economies of scale. An approach casted in iron when the Court of Justice also used the opportunity to revisit Commercial Solvents retroactively, interpreting a foreclosure risk in this despite the original wording of the ruling, largely ignoring the issue. ${ }^{28}$

While it might represent a mis- or overinterpretation to extract too much from Night Service, it would take a deaf to ignore the message sent from Bronner. The requirement of exceptional circumstances should be taken seriously. A requirement explained beautifully by the General Advocate, but regrettably not cited in the ruling ${ }^{29}$ when he noted that "In the long term it is generally pro-competitive and in the interest of consumers to allow a company to retain for its own use facilities which it has developed for the purpose of its business. For example, if access to a production, purchasing or distribution facility were allowed too easily there would be no incentive for a competitor to develop competing facilities. Thus while competition was increased in the short term it would be reduced in the long term. Moreover, the incentive for a dominant undertaking to invest in efficient facilities would be reduced if its competitors were, upon request, able to share the benefits. Thus the mere fact that by retaining a facility for its own use a dominant undertaking retains an advantage over a competitor cannot justify requiring access to it".

Trough Magil, Night Service and Bronner, a doctrine has emerged, reserving intervention to exceptional circumstances essentially defined as the presence of two vertically linked markets and a foreclosure risk on the later absent delivery, service or license on the first. ${ }^{30}$ Further, by revisiting Commercial Solvents, the Court appeared to have aligned refusal to service new

\footnotetext{
${ }^{28}$ Case C-7/97 - Oscar Bronner, ECR. 1998 p. I-7791, recital 38.

${ }^{29}$ See recital 57 of the General Advocate opinion.

${ }^{30}$ Elements can also be extracted from case T-504/93 - Tiercé Ladbroke, ECR. 1997 p. II 923, decided parallel to these cases.
} 
customers with termination of existing, making distinctions redundant. A doctrine that at the same time could be considered both wider and narrower compared to the initially tabled Essential Facility Doctrine. Wider in its requirement of access to a market rather than merely the naked infrastructure facility, thereby implying that delivery could include less essential facilities and products if a precondition for effective access. ${ }^{31}$ Narrower when requiring two separate products and markets, vertically linked, where one could be labelled essential for the second, thereby excluding vertically integrated products with no (or little) demand for the unbundled products.

\section{The notion of a new product and the ghost of past Christmas}

While it might be possible to view, in particular, Bronner as an attempt by the Courts to align the different doctrines into a single, relatively easily applicable (and narrow), doctrine, this was shattered with the judgment in $I M S^{32}$ in 2004. Further, this was done in a situation where the General Court already had declined to accept interim relief overturning the Commission decision on the matter. ${ }^{33}$ Here the Court of Justice once again was called to clarify when to label a refusal to license as abusive under Article 102. Echoing the principles offered in Bronner, the Court of Justice reserved intervention for exceptional circumstances, requiring two separate products and a potential foreclosure in the absence of alternatives, including less attractive alternatives. However, then the Court decided to add something new. Firstly, and perhaps neither unexpected nor controversial, by noting that it was not required that products or services currently were marketed independently if a potential demand, and hence a market, for these existed. It was therefore sufficient that a hypothetical market could be identified. Secondly, and of much more far-reaching consequence, the Court then noted how the refusal could suppress the tabling of new products or services for which there was consumer demand. A consideration initially offered in Magil but subsequently largely ignored. As both cases, in contrast to Bronner, had dealt with the refusal to license IP rights and both, also in contrast to Bronner, had articulated the suppression of new products requested by the consumers, it would be difficult not to conclude that two separate doctrines had prevailed. One for dealing with the refusal to supply of non-IP rights requiring two products and a likely foreclosure, and a more rigid reserved for IP rights

\footnotetext{
${ }^{31}$ For a critical assessment of this, see e.g. Nicolas Petit, Circumscribing the Scope of EC Competition Law in Network Industries? A Comparative Approach to the US Supreme Court Ruling in Trinko, Journal of Network Industries, 5: 2004 pp. 347-362.

${ }^{32}$ Case C-418/01 - IMS Health, ECR. 2004, p. I-5039. See in particular recitals 29, $37-45$ and 49.

${ }^{33}$ Case T-184/01R - IMS Health v. Commission. See in particular recitals 96, 100 and 101-102.
} 
also requiring a new product subject to consumer demands. A doctrine that in theory should preclude situations of downstream competition, and hence would stand out as significantly more attractive from the perspective of the dominant undertaking. Further, in its decision overturning the Commission's initial granting of interim relief, the General Court had specifically noted that unlike Magil no new products were offered in the case, indicating that all the parties were acutely aware of the issue when IMS was delivered by the Court of Justice.

The problem and potential damage were, however, much more grievous than merely the emerging of a new and more rigid doctrine. A not to unfamiliar event under competition law in light of its high dependency on actual cases and doctrines extracted from these. At the time of deciding IMS, the Commission had been in the process of finalizing what would become $\mathrm{Mi}$ crosoft I. Anticipating, ${ }^{34}$ if not the outcome of IMS, at least its potential damage, the Commission accelerated the delivery of its Microsoft decision, tabling it a month prior to IMS. A prudent move as the case also involved the non-license of IP rights but no new products. ${ }^{35}$ Under a rigid and formal application of IMS and the "new product requirement", no abusive refusal could therefore be identified. A not particular attractive outcome taking the considerable time and resources invested by the Commission into considerations. ${ }^{36}$ Reviewing the case, the General Court sided with the Commission and concluded in Microsoft I, ${ }^{37}$ from 2007, that the issue of a new product articulated by the Court of Justice in Magil and IMS, and accepted by itself in the latter, was not a legal requirement but merely an example of how consumers could suffer from lack of licensing. Hence, once again the doctrines had been aligned, forming a single coherent doctrine requiring two products and markets and a potential foreclosure of one of these in the absence of viable alternatives. Further, some flexibility of the latter could reasonably be extracted from the case as the (illegal) refusals at the time of the ruling had spanned almost a decade. A plaintiff would therefore not be required to

${ }^{34}$ It remains open whether the Commission had a prior warning of the outcome of IMS and its potential articulating of a new product requirement. However, in light of the unsuccessful attempt to secure interim relief and the General Court decline in the absence of a new product, it would be fair to contemplate this.

${ }^{35}$ Just like Magil, it appears that the Commission was somewhat unwilling in accepting the disputed information as IP rights. It was, however, eventually accepted.

${ }^{36}$ The lineage of the case can be traced back to a complaint logged in 1998. However, the Commission's interactions with Microsoft began much earlier. See e.g. XXIV Report of Competition Policy (1994) p. 364.

${ }^{37}$ Case T-201/04 - Microsoft Corp. ECR 2007, p. II-3601. See in particular recital 643. 
demonstrate actual foreclosure, but merely that this would eventually be plausible, which significantly lifted the plaintiff's burden of proof.

\section{Post Microsoft I and a reopening of the discussions on multiple doctrines}

With Microsoft I it had been settled that IP rights were not subject to a separate and more rigid doctrine. Further, with Clearstream $^{38}$ from 2004 it was even indicated that discriminatory refusals were, in principle, subject to the same fundamental requirement of exceptional circumstances and of a product or service indispensable for the ability to enter, or remain, viable on a linked market. When adopting the Enforcement Paper ${ }^{39}$ in 2008, the Commission could therefore summarize that a refusal could be considered abusive if "a) the refusal relates to a product or service that is objectively necessary to be able to compete effectively on a downstream market", b) "the refusal is likely to lead to the elimination of effective competition on the downstream market, and" c) "the refusal is likely to lead to consumer harm." In contrast had potential sub-doctrines been suggested in the previous Discussion Paper ${ }^{40}$ from 2005, e.g. in respect to technical information required to ensure interoperability. Here, such information could rarely be retained for the sole use of the proprietor. A not particular elaborate attempt to provide cover for the Commission's position in Microsoft I.

Regrettably would this position of relative tranquillity and balance in the force not be maintained very long as the next set of cases and rulings were mustering at the gate. Despite reserving the right to review disruption of supplies separately to a de nova refusal in the Enforcement Paper, ${ }^{41}$ there were few indications that this should be taken literally beyond the obvious. That an unexpected and erupt termination could shake most companies, in particular if they have undertaken what the Commission referred to as "relationship-specific investments" and hence become dependent on continuous supplies. However, in Sot Lélos ${ }^{42}$ from 2008, the Court of Justice decided to cite Commercial Solvents rather than Bronner when called to clear when to

${ }^{38}$ COMP/38.096 - PO/Clearstream (Clearing and settlement). See recital 227, where Bronner and its criteria are applied to a discriminatory refusal to supply.

${ }^{39}$ Guidance on the Commission's Enforcement Priorities in Applying Article 82 EC Treaty to Abusive Exclusionary Conduct by Dominant Undertakings, recital 81.

${ }^{40}$ DG Competition discussion paper on the application of Article 82 of the Treaty to exclusionary abuse, recital XX. See also recital 218, where disruption of current supplies are identified as a (potential) separate set of abusive behaviour.

${ }^{41}$ Guidance on the Commission's Enforcement Priorities in Applying Article 82 EC Treaty to Abusive Exclusionary Conduct by Dominant Undertakings, recital 84.

${ }^{42}$ Case C-468/06 - 478/06 - Sot Lélos v. GlaxoSmithKline, ECR 2008, p. I-7139. 
consider a reduction in supplies abusive. ${ }^{43}$ The case related to the re-export of pharmaceutical products and the decline to supply products beyond what was realistically required for domestic use and should be evaluated in the light of this. While some authors simply ignore the ruling, others attribute it to a separate category of abusive behaviour harmful to the single market ${ }^{44}$ and hence, limit its implications for the general refusal to supply doctrine. While much sympathy could be offered in respect to the latter position, it would not be prudent to neglect the issue entirely. In particular as the Commission have occasionally revealed itself as a subscriber to the idea of separate doctrines. Most clearly in the Discussion Paper, ${ }^{45}$ serving as a draft for the Enforcement Paper, but also visible in the later. Even more turbulence has emerged in the wake of Microsoft I as rumours started to leak shortly after its decision, including that it was decided by a narrow majority of judges, ${ }^{46}$ indicating how divided the court was in 2007. Consequently, much effort has been made to extract clues from Microsoft $I I^{47}$ from 2012. A case not dealing indirectly with refusals to supply, but merely with the magnitude of the fine to be levied upon Microsoft for failing to stop its illegal refusals as ordered by the Commissions in 2004. As a warm up to its legal rationing, the General Court opened Microsoft II by citing IMS and the new product requirement, noting that these where meet in Microsoft I. Labelling this as incorrect would, as detailed earlier, be a mild understatement, indicating that either the General Court expressed itself somewhat untimely or decided to use the opportunity to reopen the discussions. Regardless of the options, little can be said to have been settled beyond the requirement of two markets and some kind of foreclosure risk.

\section{Refusal to supply in Danish law - A somewhat slow incorporation}

As indicated initially, a somewhat light handed doctrine on refusal to supply had developed under Danish competition law. Partly due to the lack of alignment with EU law. A lacuna that would be remedied in 1997 with the adoption of an EU conform Competition Act, incorporating provisions mirroring Article 101 and 102. Further, the governing EU principles were articulated into the preparatory work, identifying an abusive refusal if a domi-

\footnotetext{
${ }^{43}$ Revisiting case COMP/38.096 - PO/Clearstream (Clearing and settlement), recitals 242-243, the same consideration can be identified here.

${ }^{44}$ See e.g. Richard Whish and David Bailey, Competition law, $7^{\text {th }}$ edition, Oxford 2012, p. 711.

${ }^{45}$ DG Competition discussion paper on the application of Article 82 of the Treaty to exclusionary abuse, recital 218.

${ }^{46}$ See Stephanie Bodoni and Matthew Newman, Microsoft Settled EU Case Not Knowing Vote Was 7 to 6, Blomberg, 5 September 2008.

${ }^{47}$ Case T-167/08 - Microsoft v. Commission. See recitals 139-140.
} 
nant undertaking, without objective reasons, denied access to supplies considered material. ${ }^{48}$ It is not entirely clear why the word material, in Danish vasentlig, was chosen over essential when it must have been clear in 1997 that EU had moved on in favour of a restrictive doctrine abandoning early practice as Commercial Solvents. More important, the decision appears to have had an impact as a number of decisions delivered around the end of the millennium today would stand out as manifestly wrong. Examples of these are Montana M bbler $^{49}$ from 1998 and Jydsk Camping ${ }^{50}$ from 2000. In the first, the Danish Competition Authority had in support of the obligation to supply certain design furniture offered that these where material for the perception of being a serious dealer of exclusive furniture. In the latter, it was held that the consumer preference for the disputed products was so strong in Denmark that it could be considered essential to include them in the selection. In a modern perspective, neither of these would pass the essentiality test formulated with Bronner, indicating a problematic (early) alignment to EU's principle ${ }^{51}$ and room for improvement.

\section{EU conformity would gradually be secured}

Despite the somewhat less successful translation of Article 102 into Danish law, alignment would gradually be secured, and Jydsk Camping would in reality be the last case identifying a clear obligation to supply. ${ }^{52}$ Further, with Dansk Taxi Forbund ${ }^{53}$ from 2001, references are for the first time made to Bronner. However, only by the parties before the appeal board and in vain as the underlying decision identifying an obligation to supply was upheld. However, with Spilleautomatbokse $e^{54}$ from 2003, Bronner is incorporated fully, rendering the request for supplies dismissible in the presence of alternatives. It is even more clearly articulated in Canal Digital og TV

${ }^{48}$ Folketingstidende 1996-97, Tillæg A, Bind IV, p. 3669.

${ }^{49}$ Leveringsnaegtelse - Montana Møbler A/S /P. Lindegaard Poulsen ApS, Competition Council meeting, 27 May 1998. See also Leveringsnagtelse fra $B \& O$ overfor Merlin, Competition Council meeting 25 November 1998 for the same liberal approach.

${ }^{50}$ Jydsk Camping Industri A/S meddelt påbud om levering af selskabets fortelte, Competition Council meeting 31 Maj 2000.

${ }^{51}$ It should also be noted that it appears equally unlikely, in a modern perspective, that a dominant position should be identified in the first place, indicating another area where early Danish practice failed.

${ }^{52}$ The statement is subject to some reservation as an obligation was indicated, but never finalized in a few subsequent cases. Further, as detailed below, a few cases dealing with collective refusals to supply have been assessed under the Danish equivalent of Article 101.

${ }^{53}$ Dansk Taxi Forbund Centralforeningen af Taxiforeninger m.fl. mod Konkurrencerådet, decision by the Competition Appeal Board dated 16 January 2001.

${ }^{54}$ Klage over nagtelse af adgang til modaliteter til formidling af oplysninger fra spilleautomater til Spillemyndigheden, Competition Council meeting 18 June 2003. 
$Z_{u l u}^{55}$ from 2004, requiring exceptional circumstances in order to make a request for supplies admissible.

While reference to Bronner only appears with some time lag, IMS should quickly be incorporated, leading to a division of doctrines. ${ }^{56}$ Not always successfully. In the absence of a new product, no obligation to license could e.g. be identified in $S A P^{57}$ from 2004, leading to a dismissal of the logged complaint. Most likely a correct conclusion that, however, seems to disregard the Commission's approach to Microsoft available at the time of SAP, making the offered ration somewhat inadequate. Other problematic Danish cases are $S a k k{ }^{58}$ from 2002 and Bekampelse af minksygdomme from $2006 .{ }^{59}$ Neither of them identifies any obligation to supply, and while the conclusions appear solid, the same can regrettably not be said in respect to the offered legal analysis and rationing supporting these. In the first, no abuse is held on the ground of a combination of objective reasons and lack of essentiality rather than a formal application of the Bronner criteria, while the latter is closed without any reference to these at all. Perhaps even more troublesome is the manner in which the Bronner criteria are applied in Scek$k o$. Rather than consider the ability to remain viable absent delivery, thereby qualifying the essentiality of the requested product objectively, the Competition Council confines itself to note that it would only amount to a very small percentage of plaintiffs' turnover. This indicates a much more subjective interoperation of Bronner than outlined above, with the form of a de minimis analysis rather than focusing on exceptional circumstances and likely consumer harm.

As none of the cases, post Jydsk Camping, identifies an abusive refusal, general principles should perhaps only be extracted with cautiousness. On the other hand, they do indicate room from improvements before a clear, and EU conform, doctrine could be said to have been developed under Danish practice. More recent practice, however, appears to have closed the gap, securing full alignment. In Terminal $A^{60}$ from 2012, a case dealing with the lease of land for the purpose of constructing a new and competing passenger

${ }^{55}$ Distributionsaftale mellem Canal Digital A/S og TV2 Zulu A/S, Council meeting 28 April 2004. See in particular recital 66.

${ }^{56}$ See e.g. Konkurrenceredegфrelsen 2006, pp. 290-291.

${ }^{57}$ Klager over SAP Danmark A/S, Council meeting, 24 November 2004.

${ }^{58}$ Sakke A/S har ikke overtrådt forbuddet mod misbrug af dominerende stilling, Council meeting 27 November 2002.

${ }^{59}$ Konkurrencerådet vinder sag om bekcempelse af minksygdomme, decision by the Competition Appeal Board dated 4 December 2006.

${ }^{60}$ Terminal A - Konkurrencerådets beslutning om at rette henvendelse til transportministeren af 25. januar 2012, Council meeting 12 January 2012. See recitals 1106 and 1116-1256. 
terminal in Copenhagen Airport, Bronner is applied correctly. That involves reciting the criteria established by Bronner and confirmed with $I M S$ and $M i$ crosoft $I$, requiring two linked markets and a foreclosure risk followed by discussions on the risk of the latter in the absence of alternatives to the land and ground controlled by the airport. In this process, the two separate product markets are the provision of a) access to runway facilities and the related infrastructure and b) terminal and ancillary commercial services to passengers and airline companies followed by substantial analysis supporting that only Copenhagen Airport, through the leasing of land, could secure access to the latter. ${ }^{61}$ Intervention under Article 102 and section 11 of the corresponding Danish act was therefore warranted, and had it not been for the somewhat late uncovering of regulation preventing the intended unbundling of services, an obligation to supply would most likely had been established.

\section{Objective justification in Danish practice}

Taken the somewhat light handed refusal to supply doctrine that initially had been developed in Danish practice, it should not be a surprise that substantial intellectual efforts had been invested into developing a lengthy catalogue of objective justifications warranting exception from the obligation. In addition to the obvious ones, e.g. (substantial) technical challenges or lack of money and qualifications under a selective distribution system, this includes past (and repeated) infringements of the proprietor IP rights, ${ }^{62}$ failure to respect contractual obligations ${ }^{63}$ and lack of economies of scales when supplying small orders. ${ }^{64}$ Further, and most interesting, it had been accepted in (old) Danish practice that an obligation to service a direct competitor rarely should emerge ${ }^{65}$ A position presumable echoing the conclusions fol-

${ }^{61}$ The case suffers from a potential flaw by postulating that a separate market for the construction and operating of airport terminals separately from the remaining airport activities can be identified. In support of this, a few, but not particular clear, examples of airports separating the terminal activities are provided in recitals 361-378. Should the presumption prove wrong, the case would lapse in the same manner as Night Service, making an overturn in an appeal plausible. Further, the market subject to an access request is in reality the market for the operation of airport services rather than a secondary market placed downstream. This would represent another novel interpretation of EU practice as indicated above by involving horizontal foreclosure rather than vertical. As the case never was finalized, both issues remain dormant.

${ }^{62}$ See e.g. Stokke Danmark ApS v. Konkurrencerådet, decision by the Competition Appeal Board dated 5 December 1997.

${ }^{63}$ Toyota v. Konkurrencerådet, decision by the Competition Appeal Board dated 16 March 2006.

${ }^{64}$ See e.g. Dansk Reklamefilms A/S' standardaftaler, Council meeting 22 June 2006 accepting a minimum purchase obligation despite exclusion of certain (minor) customers.

${ }^{65}$ Sportsdykkerforbundets blad v.Konkurrencestyrelsen, decision by the Competition Appeal Board dated 29 September 1998. 
lowing early EU cases as $U B S$, but which on the other hand fails to notice the dislike demonstrated by the Commission subsequently. ${ }^{66}$ No comments are e.g. offered on the matter in any of the submissions summarizing the legal obligation. Neither the Access Notice, the Discussion Paper nor the Enforcement Paper gives any indication of such a doctrine. The only indication in this direction is made in the Access Notice, dealing with the telecommunication sector and the need here to secure a balance between shared access to existing (and old) infrastructure and the investments in new. Here, the Commission notes that ${ }^{67}$ in addition to "... overriding difficulty of providing access to the requesting company" it might also be required to take "the need for a facility owner which has undertaken investment aimed at the introduction of a new product or service" into consideration in order to secure him "sufficient time and opportunity to use the facility in order to place that new product or service on the market." While no general exemption should be offered for competition reason, it might be relevant to accept regulatory holidays and some immunity for new investments. ${ }^{68}$ The already cited Jydsk Camping offers another interesting example of exemptions (not) available in Danish practice by indicating that capacity restraints would not be a lasting excuse. If required, supplies could be rationed securing all equal access to the secondary market. Presuming full alignment with the rigid conditioning outlined by Bronner has been secured in Danish practice, it would be equally plausible to presume that most of the Danish exceptions have become redundant unless reflected in EU practice.

\section{When all roads lead to Golgata - Other available doctrines}

As indicated initially, other doctrines opening for an obligation to supply could be available. Following Telefónica ${ }^{69}$ from 2007 and Telekomunikacja

${ }^{66}$ Decoding the details of Terminal A, it might be possible to view the case as dealing with horizontal foreclosure, thereby indicating an overturn of the old Danish practice. The case was regrettably newer finalized. Further, the case makes no reference to the old practice and the difference between vertical and horizontal foreclosure, making it difficult to extract any conclusive on the matter.

${ }^{67}$ Notice on the application of the competition rules to access agreements in the telecommunications sector - framework, relevant markets and principles. O.J. 1998C 265, pp. 2-28, recital 91e.

${ }^{68}$ On the other hand, the Commission has in practice respected that only vertical foreclosure should be pursued under Article 102, refrained for condemning undertakings refusing access to the "core" market in particular as this would de facto amount to a ban on being dominant.

${ }^{69}$ COMP/38.784 - Telefónica, recital 302-309. Confirmed by case T-336/07 - Telefónica, SA and Telefónica de España, SAU, recital $180 \mathrm{og}$ C-295/12P - Telefónica, SA and Telefónica de España, SAU v. Commission, recital 95-99. 
Polska ${ }^{70}$ from 2011 it might be possible to view constructive refusals to supply, e.g. the use of unreasonable prices and delayed opening of access negotiations, as separate form of abuse. Abuses subject to a less restrictive standard as the Commission explicitly refused to apply Bronner to the behavior under review. Further, in the Commission's Access Notice ${ }^{71}$ from August 1998, a distinction is made between refusals when access has already been granted to another customer and situations where this is not the case. The first situation is then labelled discriminatory followed by "...In general terms, the dominant company's duty is to provide access in such a way that the goods and services offered to downstream companies are available on terms no less favourable than those given to other parties, including its own corresponding downstream operations. "72 Danish practice has picked up on this. In Rørforeningens vvs-nummersystem og vvskatalog $^{73}$ from 2005, the use of minimum turnover requirements for admission to a catalogue is condemned as discriminatory, most likely in the absence of a reasonable explanation for the policy but without any analysis of the ability, or lack of this, to thwart competition. On the other hand, in Dansk Reklamefilms A/S' standardaftaler ${ }^{74}$ from 2006 , the use of minimum purchase obligations was not condemned despites its potential foreclosure of minor customers. Further, following Clearstream, ${ }^{75}$ from 2004, it appears that discriminatory refusals in EU practice are made subject to the same requirement of exceptional circumstances and a product, or service, indispensable for the ability to enter, or remain, viable on a linked market. That would make analysis of the issue a precondition for condemnation under Article 102. Consequently, the cited Danish practice might have become obsolete. But until clearly articulated in a case, the issue would remain somewhat unsettled.

Alternative doctrines supporting an obligation to supply might be available under Article 101 and the corresponding section 6 of the Danish Competi-

${ }^{70}$ COMP/39.525 - Telekomunikacja Polska. recital 704 and 803-807, referring to case 52/09 Konkurrensverket v TeliaSonera AB, ECR 2011 page I-527, recital 55.

${ }^{71}$ Notice on the application of the competition rules to access agreements in the telecommunications sector-framework, relevant markets and principles. O.J. 1998C 265, pp. 2-28, recitals 84-86.

${ }^{72}$ For completeness, it should be noted that in recital 85, the Commission notes that discriminatory abuse still requires a restriction of competition. The notion of the latter is, however, not developed further.

73 Kriterier for optagelse i Rørforeningens vvs-nummersystem og vvs-katalog, Competition Council meeting 27 April 2005.

${ }^{74}$ Dansk Reklamefilms A/S'standardaftaler, Council meeting 22 June 2006.

${ }^{75}$ COMP/38.096 - PO/Clearstream (Clearing and settlement). See recital 227, where Bronner and its criteria are applied to a discriminatory refusal to supply. 
tion Act. E.g. if a collective refusal to supply or license is adopted by a group of undertakings with the purpose of precluding, or hampering, a named third party. A recent Danish case could offer some light on this. In Konkurrencebegransende samordning i ejendomsmaglerbranchen, ${ }^{76}$ from 2012, a group of real-estate agents, including their trade association, representing $65 \%$ of the market, had adopted a policy of not providing pictures of real-estates offered for sale to an internet-based portal. The latter was competing with the agents' own portal, and as the pictures where covered by IP rights, it was possible to enforce the agreement effectively. In its decision upholding the condemnation, the Appeal Board noted that the agreement was neither accessory to the agents' own portal nor required to protect the IP rights. Further, as the agents represented a significant portion of the market, the policy would unavoidably put the competing portal at a disadvantageous position without concluding that this would lead to a foreclosure. Finally, it was noted that the agreement formed part of a wider policy of foreclosing the competition portal and was not an isolated instrument. Despite the cocktail of elements supporting the conclusion, the $65 \%$ market share should be singled out as the most eminent of these by mirroring the discussions on exceptional circumstances and foreclosure risk from Article 102. Despite being a different doctrine, subject to different legal requirements, it appears that collective refusals under Article 101 and section 6 follow some of the principles identified in respect to Article 102.

\section{Competition law and regulatory lacunas}

As detailed above, competition law would rarely identify an obligation to supply, limiting this to exceptional circumstances, largely defined as an unfair attempt to reserve a secondary marked. Further, as Article 102 and the Danish section 11 separate dominant and abuse, the mere position of essential inputs is insufficient to constitute an abuse. Refusal to contract is therefore never an abuse in itself, and no general obligation could emerge to make a market more competitive and most likely neither to accept entry into the market for the essential input. That does not preclude the use of competition law to correct regulatory lacunas. Under EU law, it has been accepted that competition law could serve to enforce obligations imposed under sector regulation even when the national regulator had already condemned the conduct. ${ }^{77}$ However, this would most likely not be possible under Danish

\footnotetext{
76 Konkurrencebegransende samordning i ejendomsmaglerbranchen, Competition Council meeting 25 January 2012. Upheld by Dansk Ejendomsmaglerforening m.fl. mod Konkurrencerådet, decision by the Competition Appeal Board dated 16 November 2012.

${ }^{77}$ See e.g. COMP/39.525 - Telekomunikacja Polska. recitals 803-807.
} 
law as the Danish competition law does not apply to areas subject to specific regulation. Presuming that no sector regulation is directly applicable to a refusal to supply, competition law could be used to establish this as detailed above. Further, even contractual obligation could be enforced through competition law parallel to other remedies, provided that the behaviour could be considered abusive. That means that an unfair termination of contract or request for injunctions could be regulated within a very narrow set of circumstances. 